\title{
PENGARUH ELECTRONIC WORD OF MOUTH DAN KUALITAS WEBSITE TERHADAP MINAT BELI KONSUMEN PADA MOBIL TOYOTA CALYA DI WILAYAH TANGERANG SELATAN
}

\author{
Ari Firmansyah ${ }^{1}$, Budi Permana Yusuf ${ }^{2}$, Edi Setiawan ${ }^{3}$ \\ Fakultas Ekonomi dan Bisnis Universitas Muhammadiyah Prof. Dr. HAMKA \\ Email:firmanbushido@gmail.com
}

\section{Intisari}

Penelitian ini bertujuan untuk mengetahui pengaruh Electronic Word of Mouth dan kualitas website terhadap minat beli konsumen. Data diambil dengan menggunakan kuesioner dari 100 responden masyarakat Tangerang Selatan yang mengetahui atau berminat terhadap Toyota Calya. Data diolah"menggunakan analisis regresi menggunakan IBM SPSS Statistics 25. Hasil dari penelitian Electronic Word of Mouth terhadap minat beli mengemukakan "Electronic Word of Mouth"secara parsial berpengaruh signifikan dan positif terhadap minat beli. Selain itu, Hasil penelitian menemukan bahwa kualitas website berpengaruh positif dan signifikan terhadap minat beli konsumen. Hasil dari uji simultan juga menyatakan variabel Electronic Word of Mouth"dan Kualitas website berpengaruh signifikan dan positif terhadap minat beli konsumen. Hal"dapat dilihat

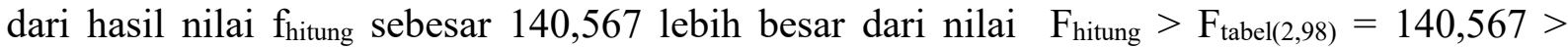
3,09"dan nilai signifikansi $0,000<0,05$, yang artinya variabel Electronic Word of Mouth dan kualitas website secara bersama-sama atau simultan"memiliki pengaruh yang signifikan terhadap minat beli konsumen. Hasil ini menunjukkan bahwa untuk meningkatkan Electronic Word of Mouth dan kualitas website"mampu meningkatkan minat beli konsumen.

Kata Kunci: Electronic Word of Mouth, Kualitas Website, Minat Beli Konsumen

\section{Abstract}

This study aims to determine the effect of Electronic Word of Mouth and the quality of the website on consumer buying interest. Data retrieved by questionnaire from 100 respondents South Tangerang people who know or are interested in the Toyota Calya. The data were processed using regression analysis using IBM SPSS Statistics 25. The results of the research Electronic Word of Mouth to express "interest in buying Electronic Word of Mouth is partially significant and positive impact on buying interest. In addition, the study found that the quality of the website and a significant positive effect on consumer buying interest. The results of the simultaneous test also declare a variable Electronic Word of Mouth and a website Quality significant and positive impact on consumer"buying interest. things can be seen from the results Fcounts 140.567 value greater than the value of Fcounts $>$ Ftable $(2,98)=140.567>3.09$, and the significance value $0.000<0.05$, which means that the variable Electronic Word of Mouth and the quality of the website together or simultaneously have a significant influence on consumer buying interest. These results indicate if the "Electronic Word of Mouth and" the quality of the website can increase consumer buying interest.

Keywords: Electronic Word of Mouth, Website Quality, Customer Buying Interest

\section{PENDAHULUAN}

Teknologi juga memberi pengaruh yang sangat besar bagi setiap konsumen sehingga konsumen dapat mengetahui dan juga dapat mengakses berbagai macam informasi. Konsumen dapat terhubung dengan sumber informasi yang penting dalam proses 
pemenuhan kebutuhan. Perkembangan teknologi mampu memudahkan seseorang mencari beragam informasi dalam waktu cepat dan terbilang murah. Bentuk komunikasi seperti ini biasa disebut word of mouth. Saat ini, Telah terjadi pergeseran paradigma untuk Word of mouth. Komunikasi word of mouth dilakukan secara bertatap muka dengan orang yang dikenal. Word of mouth dapat dilakukan di dunia maya dan cakupan yang lebih luas, dalam hitungan detik apa yang dibagikan orang lain dapat dibaca oleh jutaan orang lainnya di dunia. Electronic Word of Mouth dilakukan dengan memberi review produk, memberi rekomendasi pada konsumen lain atau berbagi pengalaman. Selain itu, saat ini sarana untuk memasarkan produk sangat banyak mulai dari menyebarkan selembaran poster, mengiklankan produk melalui surat kabar ataupun elektronik, dan juga melakukan sarana promosi melalui website. Penggunaan media electronic dan media digital sangat efisien karena pengeluaran modal yang dikeluarkan sangat sedikit. Internet telah mengubah cara-cara tradisional pembelian barang dan jasa. Para pengguna tidak lagi dibatasi oleh waktu dan faktor geografis. Internet telah membawa metode baru komunikasi dan cara-cara baru bertukar informasi sehari-hari di kalangan masyarakat. Penggunaan internet tentunya menjadi sarana yang sangat cepat dalam pencarian informasi. Tentunya setiap perusahaan akan cepat maju jika tidak memanfaatkan internet tersebut sebagai sarana informasi sekaligus menjual produk tersebut. Dalam tahun 2016 mobil LCGC dari tentunya mapu menaiki pasar di pertengahan 2016 dengan hadirnya Calya. Mobil tersebut teentunya dapat menduduki posisi 10 besar dalam pertengahan tahun 2016 yang dimana produk andalan toyota lainnya seperti avanza juga mulai goyah. Hingga November 2016, penjualannya sudah mencapai 39,8 ribu atau berada di posisi ke-6. Bahkan pada September dan Oktober, mobil ini mampu mengungguli penjualan Avanza dan berada di posisi puncak.

Berdasarkan hasil penelitian Laksmi \& Oktafani (2016) disimpulkan bahwa Electronic Word of Mouth berpengaruh secara signifikan terhadap minat beli followers Instagram Warunk Upnormal. Sama hal nya yang dikemukakan oleh Saleem \& Ellahi (2017); dan Usman \& Dyanti (2020); Sitanggang \& Hidayat (2018); dan Taungke \& Sunarti (2020) yang berpengaruh positif dalam penelitian tersebut. Namun, hal yang berbeda dengan penelitian Dewi (2020) yang dimana Hasil dari penelitian tersebut menunjukkan bahwa konsumen tidak selalu melihat apa yang direkomendasikan oleh komentar yang ada. Selain Itu, penelitian Semuel \& Wijaya (2017) memaparkan bahwa ada pengaruh positif dari website terhadap minat beli. Hal yang sama dengan penelitian Sitanggang \& Hidayat (2018); Giuma Mahfud \& Soltes (2016); Khalil, Umapathy, Goel, \& Reddivari (2019); Hidayah \& Syahputra (2017); Octavia \& Tamerlane (2017); Usman \& Dyanti (2020); Tawami \& Ain (2018); Napitupulu (2019); Jauhari, Kusumawati, \& Nuralam (2019); Permana (2020) yang berpengaruh positif terhadap penelitian tersebut. Namun hal yang berbeda disampaikan terhadap penelitian Frik \& Mittone (2019) yang mengatakan bahwa kualitas website hanya sedikit berpengaruh terhadap minat beli.

\section{TINJAUAN PUSTAKA DAN PENGEMBANGAN HIPOTESIS Electronic Word of Mouth}

Roli, Putra, \& Kalvin (2020) mengatakan Electronic Word of Mouth mengubah perilaku dan keputusan dari orang-orang dengan berkembangnya internet dan e-commerce yang dimana, orang sekarang menggunakan saran dan pendapat orang lain ketika membuat keputusan pembelian dan bahkan ketika membuat keputusan pembelian secara offline mereka menganggap informasi elektronik tentang berbagai hal.

Sitanggang \& Hidayat (2018) menerangkan jika Electronic Word of Mouth merupakan sebuah komunikasi dan pertukaran informasi antara konsumen lama dan konsumen baru, dengan menggunakan perkembangan teknologi seperti forum diskusi online, 
papan buletin elektronik, newsgroup, blog, situs review dan situs jejaring sosial media yang memfasilitasi pertukaran informasi di antara komunikator.

Selain itu, Hasan (2010:32) dalam (Taungke \& Sunarti, 2020) menjelaskan bahwa word of mouth adalah tindakan konsumen dalam memberikan informasi kepada orang lain mengenai produk atau merek.

Laksmi \& Oktafani (2016) juga memaparkan dalam melakukan melakukan kegiatan Electronic Word of Mouth ada beberapa dimensi diantarannya sebagai berikut:

1. Intensity

2. Content

3. Positive Valence

\section{Kualitas Website}

Ali (2016) dalam (Jauhari, Kusumawati, \& Nuralam, 2019) Kualitas situs web telah mendapatkan perhatian besar dari akademik dan praktisi yang setara karena peran vitalnya dalam mengembangkan niat pembelian pelanggan yang ditentukan kualitas situs web sebagai keunggulan keseluruhan atau efektivitas situs web dalam memberikan pesan yang dimaksudkan kepada audiens dan pemirsa.

Napitupulu (2019) menerangkan jika kualitas website adalah kualitas dari sebuah website mulai dari input hingga output yang dirasakan pelanggan secara menyeluruh pada semua halaman web yang terdapat pada domain yang mengandung berbagai informasi yang dibutuhkan pelanggan.

Keni; Wiendy (2019) mengungkap ada beberapa tingkat rasa percaya dipengaruh minat beli dengan indikatornya adalah website dapat dipercaya, website yang telah dikenal sebagai situs yang dapat memenuhi janjinya, dan tidak ada alasan untuk khawatir saat menggunakan website.

Kualitas website adalah suatu taktik atau metode pengukuran berdasar atas pendapat orang yang menggunakannya (Permana, 2020). Kualitas website ini juga dapat dilihat dari besarnya kontribusi terhadap kegunaan para pelanggan.

Menurut Santoso \& Anwar (2015) dalam kualitas website tentunya ada dimensi yang harus diterapkan dalam melakukan pemberian informasi melalui website, diantaranya sebagai berikut:

1. Usability

2. Information

3. Service Interaction

\section{Minat Beli Konsumen}

Sitanggang \& Hidayat (2018) memaparkan bahwa dalam minat beli konsumen tentunya akan ada potensi jika konsumen akan membeli sebuah produk atau jasa. Sebuah peningkatan dalam minat beli" seperti peningkatan terhadap kemungkinan yang dilakukan dalam pembelian. Minat beli dapat didefinisikan sebagai sebuah keinginan konsumen untuk membeli sebuah produk maupun jasa. Minat beli timbul dikarenakan konsumen sudah mendapatkan informasi cukup dalam membeli sebuah produk tersebut

Chauhan, Banerjee, \& Banerjee (2019) Minat beli konsumen adalah mempertimbangkan sebagai asumsi perilaku mereka yang sebenarnya. Konsumen berencana untuk membeli mereka produk dan layanan yang disajikan oleh kognitif, itu adalah mendefinisikan sebagai niat pembelian. Kepuasan pelanggan telah dibentuk untuk membuat hubungan antara perusahaan persepsi kualitas niat pembelian pelanggan.

Menurut Ferdinand (2002) dalam (Poernawati, 2019) bahwa minat beli dapat "diidentifikasi"melalui indikator-indikator sebagai berikut: 
1. Minat Transaksional

2. Minat Refrensial

3. Minat Preferensial

4. Minat Eksploratif

\section{PENGEMBANGAN HIPOTESIS}

\section{Pengaruh Electronic Word of Mouth terhadap Minat Beli Konsumen}

Giuma Mahfud \& Soltes (2016) Hasil penelitian menunjukkan bahwa kualitas eservice memiliki pengaruh positif pada minat beli konsumen

Usman \& Dyanti (2020) Hasil penelitian Kualitas Website terhadap Minat beli menunjukan bahwa Kualitas Situs $\mathrm{Web}$ berpengaruh signifikan terhadap minat beli dengan nilai koefisien jalur 0.161 .

Saleem \& Ellahi (2017) Studi ini menyelidiki hasil dari Electronic Word of Mouth pada niat pembelian pengguna Facebook. Ini juga mengidentifikasi faktor utama yang mempengaruhi kata elektronik mulut untuk membeli produk fashion. Sebuah survei dilakukan untuk mengumpulkan data dari 503 pengguna Facebook.

Dewi (2020) Dari hasil penelitian tersebut menunjukkan Komunikasi Electronic Word of Mouth tidak berpengaruh signifikan terhadap Buying Interest. Hasil dari penelitian tersebut menunjukkan bahwa konsumen tidak selalu melihat apa yang direkomendasikan oleh komentar yang ada, karena pada saat ini konsemen lebih banyak membeli apa yang mereka butuhkan dibanding dengan keinginan konsumen.

Taungke \& Sunarti (2020) Hasil penelitian mengungkapkan jika (1) variabel Celebrity Endorser berpengaruh signifikan terhadap Minat Beli, (2) variabel Celebrity Endorser berpengaruh signifikan terhadap Keputusan Pembelian, (3) variabel Electronic"Word"of Mouth berpengaruh signifikan terhadap Minat Beli, (4) variabel Electronic"Word of Mouth berpengaruh signifikan terhadap Keputusan Pembelian dan (5) variabel Minat Beli berpengaruh signifikan terhadap Keputusan Pembelian.

\section{Pengaruh Kualitas Website Terhadap Konsumen}

Khalil et al., (2019) Hasil Penelitian menegaskan bahwa informasi dan layanan kualitas website e-Tailing berdampak positif niat pembelian, dan akibatnya terus minat beli konsumen.

Semuel \& Wijaya (2017) Dari hasil penelitian tersebut menunjukkan bahwa ada pengaruh positif dari website. Selain itu, faktor psikologis dan budaya pengalaman nitizen memiliki efek positif pada niat beli. Selanjutnya, faktor psikologi dan pengalaman budaya ditunjukkan sebagai variabel intervening yang sempurna antara kualitas website dan minat beli.

Frik \& Mittone (2019) dengan Penelitian Faktor yang Mempengaruhi Persepsi Website Privasi Kepercayaan dan Niat Pembelian Pengguna Perilaku Ekonomi Perspektif. Hasil Peneitian menemukan bahwa keamanan, privasi (termasuk kesadaran, pengumpulan informasi, dan kontrol), dan reputasi (termasuk latar belakang perusahaan dan ulasan konsumen) memiliki efek yang kuat pada kepercayaan dan kemauan untuk pembelian, sedangkan kualitas website hanya memainkan peran marjinal..

Saputra (2018) Hasil penelitian menunjukkan bahwa terdapat pengaruh signifikan variabel kualitas website terhadap perceived flow. Kemudian perceived flow berpengaruh secara signifikan terhadap kepuasan pelanggan dan minat beli. Akan tetapi pada kepuasan pelanggan ditemukan tidak berpengaruh signifikan terhadap minat beli konsumen Traveloka.

Octavia \& Tamerlane (2017) Hasil penelitian tersebut menunjukan adanya pengaruh yang signifikan pada kualitas website terhadap e-trust, dan e-trust pada niat 
pembelian secara online. Selain itu, ada dampak signifikan pada kualitas situs terhadap niat pembelian secara online.

Hidayah \& Syahputra (2017) Berdasarkan hasil uji hipotesis secara keseluruhan usability pada kualitas website berpengaruh secara signifikan terhadap minat beli Terminal Wisata Grafika Cikole.

Keni; Wiendy (2019) juga menjelaskan kualitas website berdasarkan hasil penelitian ini didapatkan juga bepengaruh positif dan signifikan terhadap kepercayaan, yang sesuai dengan penelitian terdahulu oleh Shahnaz dan Wahyono (2016). Hal ini membuktikan bahwa konsumen perlu kualitas website yang baik, dengan memperhatikan keseluruhan atribut.

\section{Pengaruh Electronic Word of Mouth dan Kualitas Website terhadap Minat Beli}

Sitanggang \& Hidayat (2018) hasil penelitian yang di dapatkan"bahwa Electronic Word of Mouth dan Kualitas Website mempengaruhi Minat Beli konsumen Warunk Upnormal di Kota Bandung sebesar $42,9 \%$, sedangkan sisanya sebesar $57,1 \%$ dipengaruhi oleh faktorfaktor lainnya seperti price, service dan brand"image.

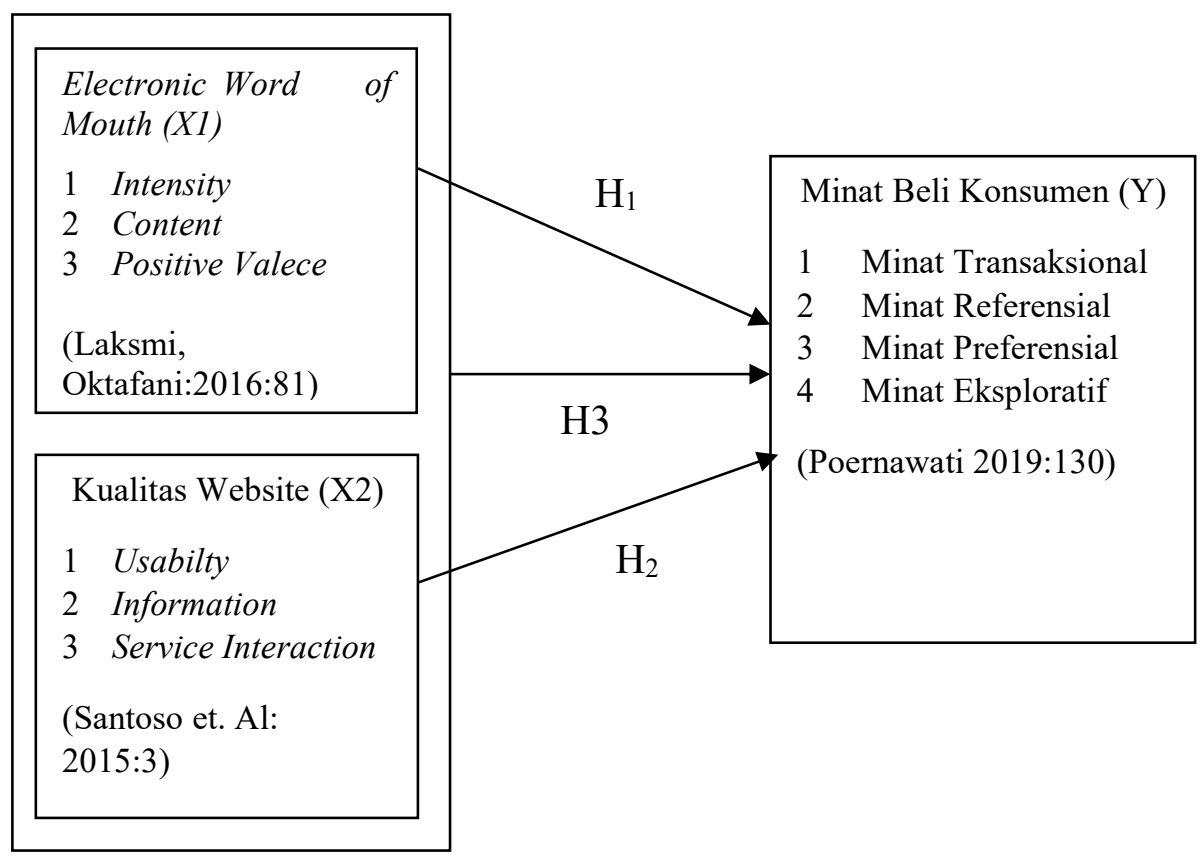

\section{Gambar 1 Kerangka Pemikiran}

\section{METODE PENELITIAN}

Metode penelitian yang digunakan adalah metode penelitian kuantitatif, populasi yang digunakan adalah masyarakat wilayah Tangerang Selatan dan sekitarnya yang telah mengenal atau minat terhadap mobil toyota calya dan sampel yang diambil sebesar 100 orang dengan tenknik pengambilan sampel jenuh dan accidental sampling.

\section{HASIL DAN PEMBAHASAN Uji Validitas}

Pada tabel 1 menunjukan bahwa terdapat 10 pertanyaan Electronic Word of Mouth

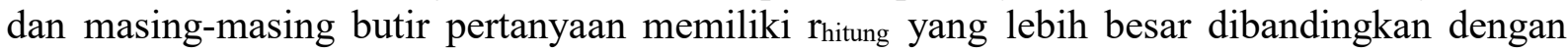
$\mathrm{r}_{\text {tabel }}$ maka dapat disimpulkan jika 10 butir pertayaan dari Electronic Word of Mouth valid sesuai dengan pernyataan jika tingkat signifikan beradah dibawah 0,05. Selain itu, 
menunjukan bahwa terdapat 10 butir pertayaan kualitas website dan masing-masing butir

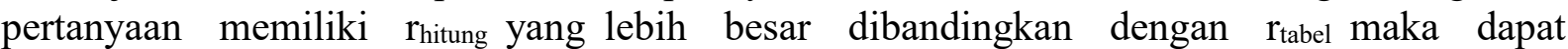
disimpulkan jika 10 butir pertayaan dari kualitas website valid sesuai dengan pernyataan jika tingkat signifikan beradah dibawah 0,05. Untuk Minat Beli Konsumen menunjukan bahwa terdapat 8 butir pertayaan minat beli konsumen dan masing-masing butir pertanyaan memiliki

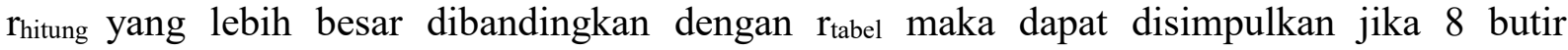
pertayaan dari minat beli konsumen valid sesuai dengan pernyataan jika tingkat signifikan beradah dibawah 0,05 .

\section{Tabel 1 Uji Validitas}

\begin{tabular}{|c|c|c|c|c|c|c|c|}
\hline \multicolumn{6}{|c|}{ Variabel } & \multirow[b]{2}{*}{ Rtabel } & \multirow[b]{2}{*}{ Ket } \\
\hline \multicolumn{2}{|c|}{ Electronic Word of Mouth } & \multicolumn{2}{|c|}{ Kualitas Website } & \multicolumn{2}{|c|}{ Minat Beli Konsumen } & & \\
\hline Butiran 1 & 0,798 & Butiran 1 & 0,767 & Butiran 1 & 0,790 & 0,1946 & Valid \\
\hline butiran 3 & 0,820 & butiran 3 & 0,835 & butiran 3 & 0,762 & 0,1946 & Valid \\
\hline butiran 4 & 0,811 & butiran 4 & 0,852 & butiran 4 & 0,874 & 0,1946 & Valid \\
\hline butiran 5 & 0,851 & butiran 5 & 0,832 & butiran 5 & 0,847 & 0,1946 & Valid \\
\hline butiran 7 & 0,867 & butiran 7 & 0,831 & butiran 7 & 0,818 & 0,1946 & Valid \\
\hline butiran 8 & 0,866 & butiran 8 & 0,847 & butiran 8 & 0,776 & 0,1946 & Valid \\
\hline butiran 9 & 0,831 & butiran 9 & 0,836 & & & 0,1946 & Valid \\
\hline butiran 10 & 0,806 & butiran 10 & 0,808 & & & 0,1946 & Valid \\
\hline
\end{tabular}

Sumber : Output SPSS Versi 25, 2020

\section{Uji Reliabilitas}

Tabel 2

Uji Reliabilitas Electronic Word of Mouth dan Kualitas Website Terhadap Minat Beli Konsumen

\begin{tabular}{|c|c|c|c|}
\hline Variabel & Standar Reliabilitas & $\begin{array}{c}\text { Cronbach's } \\
\text { Alpha }\end{array}$ & Keterangan \\
\hline Electronic Word of Mouth & 0,60 & 0,857 & Reliabel \\
\hline Kualitas Website & 0,60 & 0,903 & Reliabel \\
\hline Minat Beli Konsumen & 0,60 & 0,888 & Reliabel \\
\hline
\end{tabular}

Sumber : Output IBM SPSS versi 25, 2020

Hasil nilai Crobanch Alpha pada variabel Electronic Word of Mouth, Kualitas Website dan Minat Beli Konsumen menunjukan nilai Crobanch's Alpha lebih besar dari (>) 0,60. Sehingga dinyatakan bahwa indikator dari kuesioner tersebut reliabel atau dapat dipercaya sebagai alat ukur variabel.

\section{Uji Statistik Deskriptif}

\section{Tabel 3 Hasil Analisis Statistik Deskriptif}

\begin{tabular}{lr|r|r||r|r} 
& \multicolumn{3}{c}{ Descriptive Statistics } & Std. Deviation \\
\hline Electornic Word of Mouth & 100 & 10 & 50 & 36.05 & 7.936 \\
\hline Kualitas Websute & 100 & 10 & 50 & 38.90 & 7.067 \\
\hline Minat Beli Konsusmen & 100 & 12 & 40 & 29.38 & 6.067 \\
\hline Valid N (listwise) & 100 & & & & \\
\hline
\end{tabular}

Sumber: Output SPSS Versi 25, 2020 
Berdasarkan tabel diatas maka analisis deskriptif statistik dapat dijelaskan sebagai berikut:

1. Variabel Electronic Word of Mouth (XI) dengan jumlah responden sebanyak 100 memiliki jawaban responden dengan rata-rata (mean) sebesar 36,05 dengan jawaban minimal 10 dan maksimal sebesar 50. Sedangkan untuk standar deviasinya sebesar 7,936.

2. Variabel Kualitas Website (X2) dengan jumlah responden sebanyak 100 orang memiliki jawaban responden dengan rata-rata (mean) sebesar 38,90 dengan jawaban minimal 10 dan maksimal 50. Sedangkan untuk standar deviasninya sebesar 7,067.

3. Variabel Minat Beli Konsumen (Y) dengan jumlah responden sebanyak 100 orang memiliki jawaban responden dengan rata-rata (mean) sebesar 29,38 dengan jawaban minimal 12 dan maksimal 40. Sedangkan untuk standar deviasninya sebesar 6,067.

\section{Uji Asumsi Klasik}

Berdasarkan tabel menunjukan bahwa nilai tolerance pada variabel Electronic Word of Mouth dan kualitas website sebesar 0,353 > 0,10 sedangkan nilai VIF pada variabel Electronic Word of Mouth dan kualitas website sebesar 2,833<10 yang terbukti tidak terjadi multikolinearitas antar variabel independent model regresi

\begin{tabular}{|c|c|c|c|c|c|c|c|}
\hline \multirow[b]{3}{*}{ Model } & \multicolumn{5}{|c|}{$\begin{array}{c}\text { Tabel } 4 \\
\text { Uji Asumsi Klasik }\end{array}$} & \multirow{2}{*}{\multicolumn{2}{|c|}{$\begin{array}{l}\text { Collinearity } \\
\text { Statistics }\end{array}$}} \\
\hline & \multicolumn{2}{|c|}{$\begin{array}{l}\text { Unstandardized } \\
\text { Coefficients }\end{array}$} & \multirow{2}{*}{$\begin{array}{c}\text { Standardized } \\
\text { Coefficients } \\
\text { Beta }\end{array}$} & \multirow[b]{2}{*}{$\mathrm{t}$} & \multirow{3}{*}{ Sig. } & & \\
\hline & & $\begin{array}{l}\text { Std. } \\
\text { Error }\end{array}$ & & & & Tolerance & VIF \\
\hline 1 (Constant) & 3.547 & 1.746 & & 2.031 & & & \\
\hline $\begin{array}{l}\text { Electornic } \\
\text { Word of } \\
\text { Mouth }\end{array}$ & 0.526 & 0.066 & 0.688 & 7.947 & 0.000 & 0.353 & 2.833 \\
\hline $\begin{array}{l}\text { Kualitas } \\
\text { Website }\end{array}$ & 0.177 & 0.074 & 0.206 & 2.379 & 0.019 & 0.353 & 2.833 \\
\hline
\end{tabular}

\section{Uji Parsial (Uji T)}

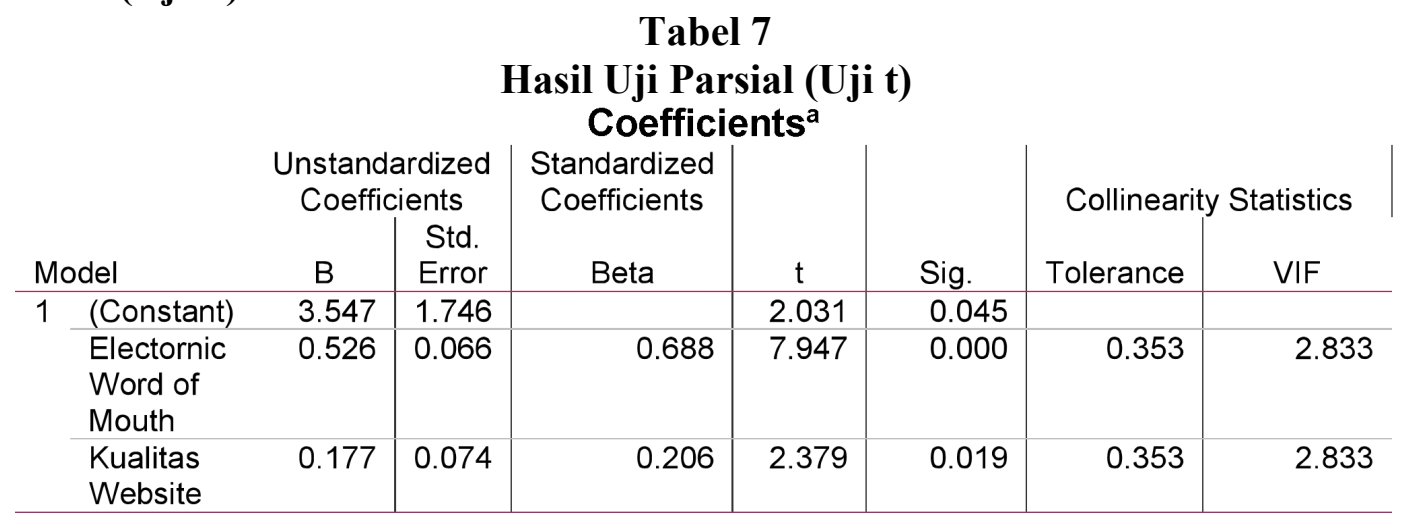

Sumber : Output SPSS versi 25, 2020

1. Uji Hipotesis Parisal (Uji t) pada Electronic Word of Mouth (X1) mempunya pengaruh yang signifikan terhadap Minat Beli Konsumen (Y). Hal ini dibuktikan karena terdapat nilai signifikan sebesar 0,000 maka $0,000<$ dari 0,05 dan $t_{\text {hitung }}>t_{\text {tabel }}$ Sebesar 7,947 $>1,98397$. Demikian H1 dapat diterima. 
2. Uji Hipotesis Parisal (Uji t) pada Kualitas Website (X2) mempunya pengaruh yang signifikan terhadap Minat Beli Konsumen (Y). Hal ini dibuktikan karena terdapat nilai signifikan sebesar 0,019 maka $0,019<$ dari 0,05 dan $t_{\text {hitung }}>t_{\text {tabel }}$ sebesar 2,379 > 1,98397. Demikian H2 dapat diterima.

\section{Uji Signifikan Keseluruhan (Uji F)}

\begin{tabular}{|c|c|c|c|c|c|c|}
\hline & & Hasil U. & $\begin{array}{l}\text { Signifil } \\
\text { OVA }^{a}\end{array}$ & $\begin{array}{l}\text { Tabel } 8 \\
\text { xan Keselu }\end{array}$ & han (U & \\
\hline Model & & Sum of Squares & $d f$ & Mean Square & $\mathrm{F}$ & Sig. \\
\hline 1 & Regression & 2708.905 & 2 & 1354.453 & 140.567 & $.000^{\mathrm{b}}$ \\
\hline & Residual & 934.655 & 97 & 9.636 & & \\
\hline & Total & 3643.560 & 99 & & & \\
\hline
\end{tabular}

Sumber : Output SPSS versi 25, 2020

Berdasarkan hasil dari tabel 4.43 bahwa nilai signifikasi sebesar $0,000<0,005$ dengan

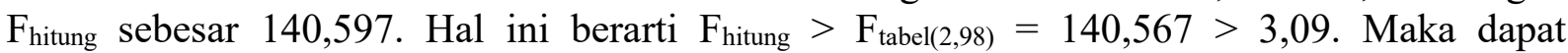
disimpulkan, Electronic Word of Mouth (X1), dan Kualitas Website (X2) secara simultan berpengaruh terhadap Minat Beli Konsumen. (Y) maka demikian H3 diterima.

\section{PEMBAHASAN}

\section{Pengaruh Electronic Word of Mouth terhadap Minat Beli Konsumen}

Berdasarkan uji t dapat disimpulkan bahwa Electronic Word of Mouth (X1) berpengaruh signifikan terhadap Minat Beli Konsumen (Y). Maka hipotesis membuktikan bahwa Electronic Word of Mouth Berpengaruh positif dan signifikan terhadap minat beli terbukti. Dari hasil menunjukkan bahwa warga melihat ulasan bagus serta mendapatkan rekomendasi dari hasil ulasan tersebut. Hasil penelitian ini membuktikan Pengaruh positif dan signifikan dari penelitian Laksmi \& Oktafani (2016); Saleem \& Ellahi (2017); dan Usman \& Dyanti (2020); Sitanggang \& Hidayat (2018); dan Taungke \& Sunarti (2020).

\section{Pengaruh Kualitas Website terhadap Minat Beli Konsumen}

Berdasarkan uji $\mathrm{t}$ dapat disimpulkan bahwa Kualitas Website (X2) berpengaruh signifikan terhadap Minat Beli Konsumen (Y). Maka hipotesis membuktikan bahwa Kualitas Website Berpengaruh positif dan signifikan terhadap minat beli terbukti. Dari data tersebut menunjukkan bahwa warga melihat ulasan bagus serta mendapatkan rekomendasi dari hasil ulasan tersebut. Hasil penelitian ini membuktikan Pengaruh positif dan signifikan dari penelitian Hasil penelitian ini membuktikan Pengaruh positif dan signifikan dari penelitian Semuel \& Wijaya (2017); Sitanggang \& Hidayat (2018); Giuma Mahfud \& Soltes (2016); Khalil, Umapathy, Goel, \& Reddivari (2019); Khalil et al., (2019); Hidayah \& Syahputra (2017); Octavia \& Tamerlane (2017); Usman \& Dyanti (2020); Tawami \& Ain (2018); Napitupulu (2019); Jauhari, Kusumawati, \& Nuralam (2019); Permana (2020) yang berpengaruh positif terhadap penelitian tersebut.

\section{Pengaruh Electronic Word of Mouth dan Kualitas Website terhadap Minat Beli Konsumen}

Dari Hasil rumus diatas menunjukan 73,8\% kontribusi pengaruh Electronic Word of Mouth dan kualitas website dapat mempengaruhi minat beli konsumen. Sedangkan, sisanya sebesar 26,2\% dipengaruhi dan dijelaskan oleh bauran pemasaran. Maka dapat 
disimpulkan, Electronic Word of Mouth (X1), dan Kualitas Website (X2) secara simultan berpengaruh terhadap Minat Beli Konsumen. (Y) maka demikian H3 diterima.

\section{PENUTUP \\ Kesimpulan}

Penelitian bertujuan untuk menguji pengaruh electronic word of mouth, Kualitas Website terhadap Minat Beli. Hasil penelitian menunjukan bahwa Electronic word of mouth berpengaruh signifikan dan positif terhadap Minat Beli Konsumen, Kualitas website berpengaruh positif terhadap Minat Beli, dan Electronic Word of Mouth dan Kualitas Website berpengaruh secara siginifikan terhadap minat beli konsumen

\section{Saran}

Bagi Konsumen

Dalam hal pemasaran melalui Electronic word of Mouth selalu menyeleksi ulasan lain dalam membeli Toyota Calya berdasarkan dari ulasan positif dari penggunan media sosial sebagai referensi. Karena, semakin seringnya melihat berbagai ulasan melalui sarana media sosial maka akan timbulnya minat beli terhadap Toyota Calya. Selain itu, penulis menyarankan setiap masyarakat untuk melihat sarana penjualan melihat website resmi sebagai referensi dalam membeli Toyota Calya. Karena, penggunaan website resmi memiliki informasi yang lengkap dan mudah di percayai, serta memiliki pelayanan yang tepat bagi setiap konsumen.

Bagi Akademisi

Penilitian ini dapat dijadikan sebagai bahan pemikiran, referensi, dan sumber-sumber penelitian lainnya yang berkaitan dengan variabel Electronic Word of Mouth, Kualitas Website, dan Minat Beli konsumen. Untuk penelitian yang berkaitan dengan variabel yang berkaitan dapat dikembangkan lagi penelitian ini dengan berbagai variabel yang bebeda

\section{DAFTAR PUSTAKA}

Chauhan, S., Banerjee, R., \& Banerjee, S. (2019). The impact of website quality and reputation on purchasing intention towards online shopping. Journal of Content, Community and Communication, 10(5), 151-158. https://doi.org/10.31620/JCCC.12.19/15

Dewi, S. puspita. (2020). Pengaruh Komunikasi Electronic Word Of Mouth Dan Security Terhadap Buying Interest Melalui Trust Sebagai Variabel Intervening Pada Online Shop Shopee (Studi Kasus Pada Mahasiswa Ust Yogyakarta). Journal of Chemical Information and Modeling, 53(9), 1689-1699.

Frik, A., \& Mittone, L. (2019). Factors Influencing the Perception of Website Privacy Trustworthiness and Users' Purchasing Intentions: The Behavioral Economics Perspective. Journal of Theoretical and Applied Electronic Commerce Research, 14(3), 89-125. https://doi.org/10.4067/s0718-18762019000300107

Giuma Mahfud, M. A., \& Soltes, V. (2016). Effect Of E-Service Quality On Consumer Interest Buying (Case Study On The Website Korean Denim). IOSR Journal of Economics and Finance, 07(04), 61-67. https://doi.org/10.9790/5933-0704016167

Hidayah, D. K., \& Syahputra. (2017). Pengaruh Usability pada Kualitas Website Menggunakan Scanmic Model terhadap Minat Beli ( Studi Kasus Terminal Wisata Grafika Cikole Lembang ). Jurnal Aplikasi Manajemen, Ekonomi Dan Bisnis, 1(2), 2135 .

Jauhari, M. T., Kusumawati, A., \& Nuralam, I. P. (2019). The Impact of Website Quality on 
Consumer Satisfaction and Purchase Intention (Study Case of E-Commerce Lazada Indonesia in Malang City). Jurnal Administrasi Bisnis, 67(1), 54-61.

Keni; Wiendy, D. (2019). Pengaruh Persepsi Kemudahan Berbelanja, Reputasi Website, Dan Kualitas Website Terhadap Minat Beli Online: Kepercayaan Sebagai Variabel Mediasi. Jurnal Manajemen Bisnis Dan Kewirausahaan, 3(1). https://doi.org/10.24912/jmbk.v3i1.4933

Khalil, H., Umapathy, K., Goel, L. C., \& Reddivari, S. (2019). Exploring Relationships Between e-Tailing Website Website Quality and Purchase Intention. Lecture Notes in Computer Science (Including Subseries Lecture Notes in Artificial Intelligence and Lecture Notes in Bioinformatics), 11588. https://doi.org/10.1007/978-3-030-22335-9

Laksmi, A. A., \& Oktafani, F. (2016). PENGARUH ELECTRONIC WORD OF MOUTH (eWOM) TERHADAP MINAT BELI FOLLOWERS INSTAGRAM PADA WARUNK UPNORMAL. Jurnal Computech \& Bisnis, 10(2), 78-88. Retrieved from www.dailysocial.id

Napitupulu, R. M. (2019). Pengaruh Usability, Information dan Service Interaction terhadap Minat Beli pada muslimarket.com. Jurnal Iqtisaduna, 4(2), 140. https://doi.org/10.24252/iqtisaduna.v4i2.5770

Octavia, D., \& Tamerlane, A. (2017). The Influence of Website Quality on Online Purchase Intentions on Agoda.Com with E-Trust as a Mediator. Binus Business Review, 8(1), 9. https://doi.org/10.21512/bbr.v8i1.1680

Permana, A. I. (2020). Pengaruh Kualitas Website, Kualitas Pelayanan, Dan Kepercayaan Pelanggan Terhadap Minat Beli Pelanggan Di Situs Belanja Online Bukalapak. Ekonomi Bisnis, 25(2), 94-109. https://doi.org/10.33592/jeb.v25i2.422

Poernawati, D. E. (2019). ANALISIS DIMENSI ELECTRONIC WORD OF MOUTH (EWOM) DAN PENGARUHNYA TERHADAP MINAT KUNJUNGAN PADA OBYEK WISATA DI MALANG RAYA. Adbis: Jurnal Administrasi Dan Bisnis, 12(2), 127-137. Retrieved from http://j-adbis.polinema.ac.id/index.php/adbis/article/view/50

Roli, T., Putra, I., \& Kalvin, M. (2020). How Electronic Word Of Mount ( E-Wom) Affects Purchase Intention With Brand Image As A Mediation Variable: Case Of Xiaomi Smartphone In Student How Electronic Word Of Mount ( E-Wom) Affects Purchase Intention With Brand Image As A Mediation Variable: . https://doi.org/10.1088/17426596/1500/1/012094

Saleem, A., \& Ellahi, A. (2017). nfluence of Electronic Word of Mouth on Purchase Intention of Fashion Products on Social Networking Websites Anum.

Santoso, B. S., \& Anwar, M. F. (2015). Analisis Kualitas Website Menggunakan Metode Webqual dan Importance-Performance Analysis (IPA) Pada Situs Kaskus. National Conference on Information Technology and Technical Engineering (CITEE), (September), 1-8. Retrieved from https://www.researchgate.net/publication/281497362 Diakses tanggal 1 Novemver 2019.

Saputra, S. W. (2018). Analisis Pengaruh Kualitas Website, Perceived Flow Dan Kepuasan Pelanggan Terhadap Minat Beli Konsumen Traveloka. 1-18. Retrieved from https://dspace.uii.ac.id/handle/123456789/8581

Semuel, H., \& Wijaya, S. (2017). The Influence of Website Quality, Psychographic Factors and User Experience to Purchase Intention, an Approach Marketing Communication Model of Traditional Indonesian Decorative Art Products. Proceedings of the Sixteenth Asia-Pacific Conference on Global Business, Economics, Finance and Social Sciences (AP17Taiwan Conference), (December), 1-14. Retrieved from www.globalbizresearch.org

Shahnaz, N. B. F., \& Wahyono, W. (2016). Faktor Yang Mempengaruhi Minat Beli 
Konsumen Di Toko Online. Management Analysis Journal, 5(4).

Sitanggang, F. C., \& Hidayat, R. (2018). Pengaruh Electronic Word of Mouth ( Ewom ) Dan Kualitas Website Terhadap Minat Beli ( Studi Kasus Pada Warunk Upnormal Di Kota the Influences of Electronic Word of Mouth and Website Quality on Intention To Buy ( Case Study in Warunk Upnormal Bandung City . 4(2), 348-356.

Taungke, G. S., \& Sunarti. (2020). PENGARUH CELEBRITY ENDORSER DAN ELECTRONIC WORD OF MOUTH TERHADAP MINAT BELI DAN DAMPAKNYA TERHADAP KEPUTUSAN PEMBELIAN (Survei pada Konsumen Erigo di Akun Resmi Instagram Erigo). Jurnal Administrasi Bisnis, 78(1), 209-218.

Tawami, T., \& Ain, A. T. (2018). Effect of Website Display on Consumer 's Buying Interest Effect of Website Display on Consumer 's Buying Interest. https://doi.org/10.1088/1757899X/407/1/012010

Usman, O., \& Dyanti, N. S. (2020). Effect of Advertising, Word of Mouth, Website Quality, and Risk Perception on Buying Interest. SSRN Electronic Journal. https://doi.org/10.2139/ssrn.3510503 